\title{
Storage and Cooling Effects on Levels of Protein Carbohydrates, Fats, Minerals and Microbes in Guinea Fowl (Numida meleagris) Meat Sold in Kaduna Metropolis, Nigeria
}

\author{
Aisha Abdullahi Bida ${ }^{*}$, Mohammed Dahiru Faruruwa \\ Department of Chemistry, Faculty of Science, Nigerian Defence Academy, Kaduna, Nigeria \\ Email address: \\ aishabeeedah@gmail.com (A. A. Bida) \\ ${ }^{*}$ Corresponding author \\ To cite this article: \\ Aisha Abdullahi Bida, Mohammed Dahiru Faruruwa. Storage and Cooling Effects on Levels of Protein Carbohydrates, Fats, Minerals and \\ Microbes in Guinea Fowl (Numida meleagris) Meat Sold in Kaduna Metropolis, Nigeria. Advances in Biochemistry. \\ Vol. 7, No. 1, 2019, pp. 10-14. doi: 10.11648/j.ab.20190701.13
}

Received: April 13, 2019; Accepted: May 30, 2019; Published: June 10, 2019

\begin{abstract}
The effect of storage and cooling time (0, 1, 3, 7 and 28 days) on the nutritional quality of guinea fowl (Numida meleagris) was assessed in terms of crude protein, moisture, ash, fat, carbohydrate, minerals (calcium, zinc, iron and potassium) and microbial content. Crude protein was determined using Kjedahl method, moisture, ash and fat content were determined using AOAC methods, carbohydrate was estimated by difference and the minerals using AAS methods (for Calcium, Zinc and Iron) and AES (for Potassium). The result of crude protein, moisture and fat content were observed to decrease as storage time increases. Moisture content ranged from 67.70 to $66.50 \%$, ash content from 0.98 to $1.01 \%$, fat content from 2.31 to $2.19 \%$, crude protein content from 20.20 to $19.13 \%$ and carbohydrate content from 8.79 to $11.17 \%$. The ash content fluctuates between the same ranges while the carbohydrate content increases with increased in storage time. The minerals content decreases with increase in storage time and the microbial analysis shows freezing inhibited the growth of bacteria which is the main cause of meat spoilage. The study showed that the meat samples could be kept in a frozen state without spoiling but the nutritional content where altered as storage time increased.
\end{abstract}

Keywords: Numida meleagris, Meat, Poultry, Storage and Cooling Effects

\section{Introduction}

In most developing countries, including Nigeria, fresh meat forms a significant proportion of meat intake [1]. It is either eaten cooked or processed into other forms to avoid associated spoilage. The main causative factor of such spoilage has been linked to unavailability of necessary storage facilities and favourable ambient temperature that usually prevail in developing countries that are in tropical regions [2]. Meat has long been considered a highly desirable and nutritious food, but unfortunately it is highly perishable because it contains the nutrients needed to support the growth of many types of microorganisms [3]. Due to its unique biological and chemical nature, meat undergoes progressive deterioration from the time of slaughter until consumption. In general, the metabolic activity of the ephemeral microbial association which prevails in a meat ecosystem under certain aerobic conditions, or generally introduced during processing, leads to the manifestation of changes or spoilage of meat [4]. These changes or spoilage are related to the type, composition and population of the microbial association and, the type and the availability of energy substrates in meat. Indeed the type and the extent of spoilage is governed by the availability of low-molecular weight compounds such as glucose, lactate existing in meat [5]. A consortium of bacteria, commonly dominated by Pseudomonas spp., is in most cases responsible for spoilage of meat stored aerobically at different temperatures $\left(-1\right.$ to $\left.25^{\circ} \mathrm{C}\right)$; the Pseudomonas spp. can grow under refrigeration temperatures $[6,7]$. It is established that under aerobic storage, three 
species of Pseudomonas, P. fragi, P. flourescens and $P$. lundensis, are the most important spoilage organisms. The population of Pseudomona to the level of 107-8 CFU/g, has been attributed to slime and off-odours formation. However, in practice both these characteristics become evident when the Pseudomona have exhausted the glucose and lactate present in meat and begin to metabolise nitrogenous compounds such as amino acids.

A common method of preserving meat in Nigeria is by refrigerating. Frozen storage causes several reactions between different meat components such as oxidative reactions that mainly occur due to the presence of oxidative catalyst in high concentration. Free radicals formed react with side chains of proteins that produce protein free radicals which on reaction with oxygen gives peroxy radicals. This has been suggested by several authors that hydroperoxides decompose to form carbonyl derivatives while sulphydryl group oxidation leads to formation of disulphide cross linkages or to the formation of mixed disulphide conjugates with glutathione, cysteine or other low molecular weight mercaptans [8, 9]. Hence, this study was carried out to determine the storage and cooling time effect on the levels of protein, carbohydrate, fat, ash, moisture and minerals in guinea fowl, a meat commonly consumed in Kaduna, Nigeria.

\section{Materials and Methods}

\subsection{Study Area}

Figure 1 shows the map of study area, Kaduna North in Kaduna metropolis, which is located between latitude $10^{\circ} 34^{\prime}$ $\mathrm{N}$ to $10^{\circ} 35^{\prime} \mathrm{N}$ and longitude $7^{\circ} 25^{\prime} \mathrm{E}$ and $7^{\circ} 36^{\prime} \mathrm{E}$.

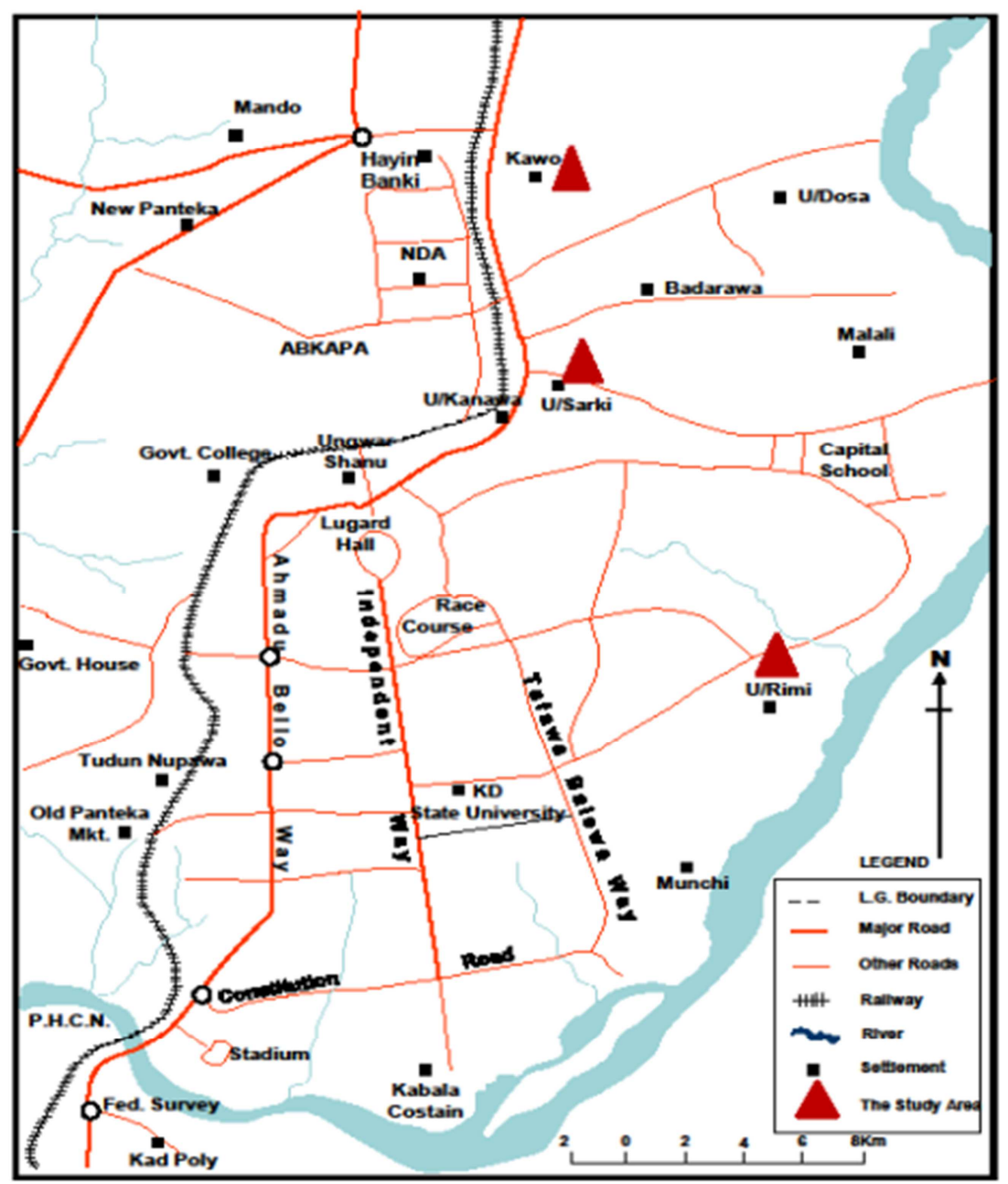

Figure 1. Map of Study Area.

\subsection{Sample Collection and Preparation}

Guinea fowls (Numida meleagris) were obtained from Kawo, Unguwan Sarki and Unguwan Rimi markets in Kaduna metropolis. Each sample was slaughtered, defeathered, washed and de-boned, and then the lean part was then finely minced. The samples were stored in a clean plastic polyethylene bag and were kept in a freezer at $17.7^{\circ} \mathrm{C}$. Each sample was analysed for protein, carbohydrate, ash, moisture content, minerals (calcium, iron, zinc and potassium) contents and microbial determination when fresh (i.e. before refrigerating) and after 1, 3, 7 and 28 days of freezing. 


\subsection{Methods of Analysis}

\subsubsection{Determination of Nitrogen and Crude Protein}

The meat sample $(2.0 \mathrm{~g})$ was weighed and placed in a Kjeldahl flask, $1.14 \mathrm{~g}$ of a mixed catalyst consisting of copper sulphate, sodium sulphate and selenium dioxide and $20 \mathrm{~cm}^{3}$ concentrated sulphuric acid were added to the sample in the Kjeldahl flask. The flask was heated in the digester and boiled until the solution became clear. Heating continued for about 30 minutes more, after heating, the flask was allowed to cool by gradually adding approximately $100 \mathrm{~cm}^{3}$ distilled, de-ionized water in a volumetric flask. To an aliquot $\left(10 \mathrm{~cm}^{3}\right)$ of the digest, $10 \mathrm{~cm}^{3}$ of $40 \% \mathrm{NaOH}$ solution was added and then connected to Kjeldahl distillation apparatus and heated to boiling. The distillate was condensed into a conical flask containing $10 \mathrm{~cm}^{3}$ of $2 \%$ boric acid and 2 drops of methyl red indicator was added and the alkaline distillate was titrated against $0.1 \mathrm{~mol} / \mathrm{dm}^{3}$ hydrochloric acid [10].

$$
\% \text { Nitrogen }=\frac{100(A \times B \times 0.014)}{C}
$$

Where $\mathrm{A}=$ Hydrochloric acid used in titration $\left(\mathrm{cm}^{3}\right), \mathrm{B}=$ Molarity of $\mathrm{HCl}$

$\mathrm{C}=$ Weight of sample $(\mathrm{g})$

$$
\text { Crude protein }(\%)=\% \text { Nitrogen } \times 6.25
$$

\subsubsection{Fat Determination}

The fat content was carried out using the procedure described by the Association of Official Analytical Chemists using soxhlet extractor apparatus [11]. 2.0g of the meat sample was weighed into porous extraction thimble and weighed. The thimble was placed in an extractor and was connected to flask containing $350 \mathrm{~cm}^{3}$ of petroleum ether (with boiling point $40^{\circ} \mathrm{C}$ to $60^{\circ} \mathrm{C}$ ) for 5 hours at condensation rate of 5-6 drops per second under reduced temperature and pressure and refluxing at $80^{\circ} \mathrm{C}$. The top was closed with cotton to minimize the escape of the extraction solvent. The fat content in the samples were exhaustively extracted in the solvent. The content of the flask was weighed and later the solvent was distilled off and the flask was reweighed. The percentage fat was then calculated using the following formula:

$$
\% \text { Fat }=\frac{\text { Wt of the Ether Extract }}{\text { Wt of the Sample }} \times 100
$$

\subsubsection{Determination of Moisture content}

Meat sample $(2.0 \mathrm{~g})$ was weighed into petri dish and placed on steam bath and heated uncovered at $102^{\circ} \mathrm{C}$ for 2 hours. The sample was reweighed and the whole process was then repeated until constant weight was obtained [11]. The percentage moisture content was calculated using the formula:

$$
\% \text { M.C } \frac{\text { Loss in Weight }}{\text { Weight of Sample }} \times 100
$$

\subsubsection{Determination of Ash Content}

Meat sample $(2.0 \mathrm{~g})$ was weighed into crucible and placed in muffle furnace, the temperature was set at $550^{\circ} \mathrm{C}$ for 8 hours. The content was re-weighed again, when cooled the whole process was repeated until constant weight was obtained [11]. The percentage ash content was calculated using the formula:

$$
\% A . C=\frac{\text { Wt of Ash }}{\text { Wt of the Sample }} \times 100
$$

\subsubsection{Determination of Carbohydrate}

The carbohydrate was determined by difference. The protein, fat, ash and moisture content of food determined were added and the sum was then subtracted from the total $100 \%$. [12].

\subsubsection{Mineral Analysis}

The minerals of interest: potassium, calcium, zinc and iron were determined using the method described below:

The meat sample $(2.0 \mathrm{~g})$ was weighed into a $50 \mathrm{~cm}^{3}$ digestion tube, $20 \mathrm{~cm}^{3}$ of acid mixture $\mathrm{H}_{2} \mathrm{SO}_{4}, \mathrm{HNO}_{3}, \mathrm{HClO}_{4}$ $(2: 1: 1)$ were added to the sample and put in fume cupboard and digested with a hot plate until a clear colourless solution was observed. The digested sample was allowed to cool and carefully filtered into a $100 \mathrm{~cm}^{3}$ volumetric flask using Whatman No. 40 filter paper and made up to the mark. Then it was transferred to a labelled plastic sample bottles and carried to the Atomic Absorption Spectrophotometer (Thermo Scientific Model: iCE vl.30) for calcium, zinc and iron determination while Flame Emission Spectrophotometer was used for potassium determination [13].

\subsubsection{Microbial Determination}

After slaughtering and pre-treatment, the meat sample was washed with sterile distilled $\mathrm{H}_{2} \mathrm{O}$. Then Nutrient agar was prepared $\left(38 \mathrm{~g}\right.$ in $1000 \mathrm{~cm}^{3}$ of distilled water) and sterilized in an autoclave for 15 mins. The sterilized agar was placed in petri dishes to solidify. The sterile water was used to wash the samples. Sterile swap stick was then used to collect the water from the meat and smear it on the solidified agar and the control which contains only the solidified agar where incubated for 24 hours at $37^{\circ} \mathrm{C}$ for bacterial growth and the procedure was repeated for the frozen samples [11].

\subsection{Statistical Analysis}

Data obtained from various analysis were analyzed using Microsoft Office Excel 2013. The data were expressed in terms of descriptive statistics while the figures were presented with Mean values as (Mean \pm SD). Analysis of Variance (ANOVA) was used to test for significance, $p$-value less than 0.05 were considered as Significant, while p-values greater than 0.05 were not significant.

\section{Results and Discussions}

The results as presented in Table 1 showed that the moisture content is slightly affected by duration of cooling 
time. The results on moisture content before refrigerating and the $28^{\text {th }}$ day after refrigerating are 67.70 and $66.50 \%$ respectively. It showed slight decrease with cooling time, meaning as the number of cooling days increases the moisture content decreases. Freezing alters both the content and the supply of moisture in meat tissue. The decrease in moisture content during cold storage may be attributed to the decreases in water holding capacity and loss of small drip $[14,15]$. Water content may be affected by the absorption of moisture during the chilling process and by any type of phosphate treatment, which favours moisture retention [16]. The result of protein level showed slight decrease during cold storage. As the number of days increases the protein content decreases. From Table 1, before refrigerating has the highest protein content with $20.20 \%$ compared to the remaining days. These effects might be due to bacterial decomposition and escaping of some soluble nitrogen compounds [14, 15]. Ash in food determines largely the extent to which the dietary minerals would be available in a food and the rate at which food substances would make available amount of energy locked in it [17]. The feed type determines the ash content of the meat. Regarding cold storage, the ash content of the samples show no significant changes during storage. The carbohydrate content of the meat samples shows day 28 has the highest while before refrigerating has the lowest. The carbohydrate content of the samples increased during refrigerating, which increased from $8.77 \%$ before refrigerating to 11.20 after $28^{\text {th }}$ day and these effects might be due to reduction of moisture level from slaughter plus the freezing period of the meat (as seen from the moisture results of this work). However George and Aguiar reported that reindeer meat can be frozen for up to a year without compromising quality in their work to determine the effect of reindeer meat quality of frozen storage for 12 months [19]. The fact that the moisture, ash, fat, protein and carbohydrate content for all the cooling days are within the USDA and ADHS recommended food storage times cold and dry refrigerated and frozen foods which is one year shows that the meat is still safe for consumption [20].

Table 1. Proximate analysis.

\begin{tabular}{llllll}
\hline Days & Moisture (\%) & Ash (\%) & Fat (\%) & Protein (\%) & $\begin{array}{l}\text { Carbohydrate } \\
(\%)\end{array}$ \\
\hline 0 & $67.70 \pm 0.13$ & $1.02 \pm 0.54$ & $2.31 \pm 0.50$ & $20.20 \pm 0.02$ & $8.76 \pm 0.56$ \\
1 & $67.69 \pm 1.47$ & $1.01 \pm 0.55$ & $2.30 \pm 0.23$ & $20.10 \pm 0.15$ & $8.90 \pm 2.06$ \\
3 & $67.56 \pm 0.24$ & $1.00 \pm 0.74$ & $2.28 \pm 0.19$ & $19.86 \pm 0.02$ & $9.30 \pm 0.69$ \\
7 & $66.89 \pm 1.72$ & $0.99 \pm 0.75$ & $2.23 \pm 0.31$ & $19.51 \pm 0.37$ & $10.38 \pm 2.12$ \\
28 & $66.50 \pm 1.20$ & $0.98 \pm 0.50$ & $2.19 \pm 0.28$ & $19.13 \pm 0.55$ & $11.19 \pm 2.11$ \\
\hline
\end{tabular}

Values are $($ mean \pm SD)

Table 2. Mineral Analysis.

\begin{tabular}{lllll}
\hline Days & Calcium $(\mathbf{m g} / \mathbf{g})$ & Zinc $(\mathbf{m g} / \mathbf{g})$ & Iron $(\mathbf{m g} / \mathbf{g})$ & Potassium $(\mathbf{m g} / \mathbf{g})$ \\
\hline 0 & $2.26 \pm 0.25$ & $0.04 \pm 0.01$ & $1.55 \pm 0.06$ & $3.60 \pm 0.23$ \\
1 & $2.24 \pm 0.26$ & $0.04 \pm 0.00$ & $1.53 \pm 0.03$ & $3.30 \pm 0.16$ \\
3 & $1.49 \pm 0.26$ & $0.03 \pm 0.00$ & $1.51 \pm 0.04$ & $2.70 \pm 0.16$ \\
7 & $1.33 \pm 0.29$ & $0.02 \pm 0.00$ & $1.49 \pm 0.03$ & $2.60 \pm 0.12$ \\
28 & $0.42 \pm 0.16$ & $0.01 \pm 0.00$ & $1.45 \pm 0.07$ & $1.80 \pm 0.84$ \\
\hline
\end{tabular}

The result as presented in Table 2 shows that the calcium content is slightly affected by duration of cooling time. Before freezing has the highest calcium content $(2.26 \mathrm{mg} / \mathrm{g})$ which decreases to $(0.42 \mathrm{mg} / \mathrm{g})$ after 28 days of freezing. Zinc content is slightly affected by duration of cooling time. Day zero has the highest calcium content $0.04 \mathrm{mg} / \mathrm{g}$ which decreases to $0.01 \mathrm{mg} / \mathrm{g}$ at day 28 after freezing. The reduction could be attributed to drip loss and dehydration that is associated with frozen storage. Zinc is a trace element involved in many body reactions which help in construction and maintenance of DNA, formation, growth and repair of body tissues, hair, skin, bones nails and teeth. It is also important in the reduction of pneumonia and diahorrea deaths among children under five years of age in developing countries. Zinc also play a role in immunity, chronic diseases and apoptosis [21]. Iron content from the analysis decreases as storage time increases from day zero to day $28^{\text {th }}$. Iron which is a trace metal has many functions in the body hence very important in maintaining healthy immune system for blood to work efficiently and transports oxygen as oxyhaemoglobin. Deficiency of iron is manifested as fatigue especially among long distance athletes. Severe deficiency of iron causes deficiency anaemia which affects many people globally especially pregnant women in developing countries [22]. Potassium from the study shows decrease with increase storage time. At day zero $3.60 \mathrm{mg} / \mathrm{g}$ and at day 28 is $1.80 \mathrm{mg} / \mathrm{g}$. Also, this reduction could be attributed to drip loss and dehydration that is associated with frozen storage.

Microbial analyses were conducted on the fresh and frozen meat samples for the days and a control. The control which contains only the nutrient agar were negative while the fresh and the frozen samples were positive with microbial growth. Bacterial growth is the main cause of meat spoilage [23]. Freezing appears to decrease the number of viable microbes present in meat. During freezing however, microbial spoilage is effectively terminated as the microbes become dormant. Unfortunately, they regain their activity during thawing.

\section{Conclusion}

From the results, it can be concluded that the levels of protein, fats, moisture, ash and minerals in guinea fowl decreases as the period for freezing preservation increases while that of carbohydrate increases. Guinea fowl meat can be kept in frozen state without spoiling but the nutritional content is altered as storage time increases. Freezing appears to decrease the number of viable microbes present. However, the microbes become dormant during freezing.

\section{References}

[1] Olaoye, O. A. and Onilude, A. A., (2010). Investigation on the Potential Use of Biological Agents in the Extension of Fresh Beef in Nigeria. World Journal of Microbiology and Biotechnol. 26, 1445-1454. 
[2] Olaoye, O. A., Onilude, A. A., Idowu, O. A., (2010). Microbiological Profile of Goat Meat Inoculated with Lactic Acid Bacteria Cultures and Stored at $30^{\circ} \mathrm{C}$ for 7 days. Food and Bioprocess Technology 33(1): 32-36.

[3] Kalalou, I, Faid, M, Ahami, A. T. (2004). Extending the shelf life of fresh minced camel meat at ambient temperature by Lactobacillus delbruekii subsp. Delbruekii. Electronic Journal of Biotechnology 7(5): 246-251.

[4] Nychas, G, J., Skandamis, P. N., Tassou, C. C., Koutsoumanis, K. P. (2008). Meat Spoilage during Distribution. Meat Science $78,77-89$.

[5] Nychas, G. J and Skandamis, P., (2005). Fresh Meat Spoilage and Modified Atmosphere Packaging (MAP). In: Improving the Safety of Fresh Meat (Sofos, J. N., ed.) Cambridge, 34-40.

[6] Stanbridge, L. H., Davis, A. R., (1998). The Microbiology of Chill-stored Meat. In: The Microbiology of Meat and Poultry (Board, R. G., and Davies, A. R., eds.). Blackie Academic and Professional, London, UK. Pp. 174-219.

[7] Koutsoumanis, K. Stamatiou, A. Skandamis, P. and Nychas, G. (2006). Development of a microbial model for the combined effect of temperature and $\mathrm{pH}$ on spoilage of ground meat and validation of the model under dynamic temperature conditions. Applied Environment, Microbiology. 72, 124-134.

[8] Decker, E. A., Xiong, Y. L., Calvert, J. T., Crum, A. D., \& Blanchard, S. P. (1993). Chemical, physical and functional properties of oxidized turkey white muscle myofibrillar proteins. Journal of Agricultural and Food Chemistry, 41, $186-189$.

[9] Xiong, Y. L. (2000). Protein oxidation and implications for muscle food quality. In: Antioxidants in muscle foods (edited by decker, E and Faustman, C.) 85-111, 113-127.

[10] AOAC, (1999) Official Methods of Analysis of the Association of Official Analytical Chemists 15,145-679.

[11] A. O. A. C. (2000). Official Methods of Analysis of the Association of Analytical Chemists, 15,935.47, 941.18.

[12] FAO (1998). Carbohydrates in human nutrition. Report of a Joint FAO/WHO Expert Consultation. FAO food and Nutrition Paper No. 66. Rome.
[13] Ayeloja, A. A., George, F. O., Shorinmade, A. Y., Jimoh, W. A., Afolabi, O. O. and Olawapo, K. D. (2014). Heavy Metal Concentration in Selected Fish Species from Eleyele Reservior Ibadan, Oyo State, South-western, Nigeria. African Journal of Environment Science and Technology; 8(7), 422427.

[14] Shawki, H. A. S. (1998). Influence of ionizing radiation on chicken meat and fish flesh. M. Sci. Thesis. Food Science, Department. Faculty, of Agriculture Zagazig Univ. Egypt.

[15] Afifi, E. A. And El-Nashaby, F. M. (2001). Microbial decontamination of some chicken meat products by gamma irradiation. Arab. J. Of Nuclear Sci and Appl. 2(5): 46-50.

[16] Priestley, R. J. (1979). Effect of Heating on Foodstuffs. International Journal of Diary Technology, 32(3), 165

[17] Ogunmola, O. O; Taiwo, O. F. and Ayankoso, A. S. (2013). The Nutritive Value of the Meat Quality of Locally Breed Chicken, Exotic Chicken and Turkey. IOSR Journal of Applied Chemistry, 3(6), 46-50.

[18] Moreki, J. C. (2012). Chemical Analysis and Sensory Evaluation of Guinea Fowl Meat Fed Diets Containing Three Cereal Grains as Energy Sources up to 12 Weeks of Age, 2 (10). 36-42.

[19] George, A and Aguiar, B. S. (2017). The Effect of Freezing and Storage Time on the Quality of Reindeer Meat. Pp 2-25.

[20] USDA, (2011). Composition and nutritional value of different raw poultry meats. USDA: https://ndb.nal.usda.gov.

[21] Yakoob, M. Y. Theodoratou, E. Jabeen, A. Imdad, A. Eisele, T. P. Ferguson, J. Jhass, A. Rudan, I. Campbell, H. Black, R. E and Bhutta, Z. a. (2011). Preventive zinc supplementation i developing countries. BMC Public health (suppl 3): S23.

[22] Soetan, k. O. Olaiya, C. O and Oyewole, O. E. (2010). The importance o mineral elements for humans, domestic animals and plants. A review. African Journal of Food science. 4(5), 200-222.

[23] Mohammed, I. M. A. And Hamid, S. H. A. (2011). Effect of chilling on microbial load of two fish species (Oreochromis niloticus and Larias lazera). Am. Journal of Food Nutrition; $1,109-113$. 